\title{
Lung inflammation in sarcoidosis: comparison of serum angiotensin-converting enzyme levels with bronchoalveolar lavage and gallium-67 scanning assessment of the $\mathrm{T}$ lymphocyte alveolitis
}

\author{
CI SCHOENBERGER, BR LINE, BA KEOGH, GW HUNNINGHAKE, \\ RG CRYSTAL
}

From the Pulmonary Branch, National Heart, Lung, and Blood Institute, and Nuclear Medicine Department, Clinical Center, National Institutes of Health, Bethesda, Maryland, USA

ABSTRACT Serum angiotensin-converting enzyme (ACE) is elevated in many patients with pulmonary sarcoidosis and has been proposed as a measure of disease activity. The present study was designed to evaluate the possible relationship between serum ACE and direct measures of the intensity of the alveolitis of pulmonary sarcoidosis as measured by bronchoalveolar lavage and gallium-67 $\left({ }^{67} \mathrm{Ga}\right)$ scans. To accomplish this, 64 measurements of serum ACE, lavage T lymphocytes, and lung uptake of ${ }^{67} \mathrm{Ga}$ were performed in 41 patients with biopsy-proven sarcoidosis. Elevations of serum ACE were found on at least one occasion in 17 patients (41\%). However, serum ACE was found to be a poor predictor of the intensity of alveolitis in sarcoidosis as assessed by the quantitation of bronchoalveolar lavage cells that were $T$ lymphocytes and by ${ }^{67} \mathrm{Ga}$ scanning. Elevated serum ACE did not predict which patients would have elevated proportions of lavage $T$ lymphocytes, which patients would demonstrate increased pulmonary uptake of ${ }^{67} \mathrm{Ga}$, or which patients would have high-intensity alveolitis as defined by a combination of these criteria. These observations suggest that while serum ACE may be useful in diagnosing sarcoidosis, it does not reflect accurately the intensity of the alveolitis of the pulmonary component of this disease.

Sarcoidosis is a chronic granulomatous disease of unknown aetiology that can affect nearly every organ in the body. Pulmonary involvement occurs in more than $90 \%$ of patients; of this group, $20-25 \%$ suffer permanent loss of lung function and $5-10 \%$ die as a result. ${ }^{1-4}$

The earliest stage of pulmonary sarcoidosis is an alveolitis characterised by a diffuse infiltration of the lung by large numbers of monocytes/macrophages and activated $T$ lymphocytes. ${ }^{4-12}$ Current concepts of the pathogenesis of pulmonary sarcoidosis suggest that it is the activated $T$ lymphocytes that attract monocytes to the lung to form building blocks for granulomata. ${ }^{13}$ In addition, the activated lung $\mathrm{T}$ lymphocytes also stimulate lung B lymphocytes in a nonspecific, polyclonal fashion, thus causing the

Address for reprint requests: Dr CI Schoenberger, Building 10, Room 6D-06, National Institutes of Health, Bethesda, Maryland 20205, USA. hyperglobulinemia that is characteristic of the disease. ${ }^{14}$

Several studies have shown that two methods, quantitation of lung $\mathrm{T}$ lymphocytes by bronchoalveolar lavage and ${ }^{67} \mathrm{Ga}$ scanning, can be closely correlated with the alveolitis of pulmonary sarcoidosis. ${ }^{6-1015}$ The proportion of $T$ lymphocytes found in bronchoalveolar lavage fluid correlates with the intensity of the mononuclear cell alveolitis observed morphologically and with the proportion of T lymphocytes that can be recovered directly from lung biopsies. In addition, the intensity of uptake of ${ }^{67} \mathrm{Ga}$ in the lung correlates with the proportion of T lymphocytes recovered by bronchoalveolar lavage.

Using these methods, patients with pulmonary sarcoidosis can be grouped into two categories. ${ }^{416}$ Those with "high intensity alveolitis" are defined as those with lavage $\mathrm{T}$ lymphocytes of $>28 \%$ together with a positive ${ }^{67} \mathrm{Ga}$ scan of the lung, and those with "low intensity alveolitis" are defined as those with 
lavage $\mathrm{T}$ lymphocytes of $\leqslant 28 \%$ or a negative ${ }^{67} \mathrm{Ga}$ scan or both. The utility of this classification is illustrated by the prospective evaluation of untreated patients with pulmonary sarcoidosis: of those with high intensity alveolitis, approximately $62 \%$ will deteriorate in one or more lung function parameters over the subsequent six months. In contrast, fewer than $8 \%$ of individuals with low intensity alveolitis will deteriorate over the same time period. ${ }^{16}$

In this context, the present study was designed to compare the intensity of the alveolitis of sarcoidosis with measurements of serum ACE activity, a test that is used in the diagnosis of sarcoidosis and has been suggested as a useful measure of the activity of disease in these patients. To accomplish this, serum ACE was measured in 41 patients with biopsyproven pulmonary sarcoidosis and compared with lavage and ${ }^{67} \mathrm{Ga}$ estimates of the alveolitis made at the same time.

\section{Methods}

The study population consisted of 41 individuals with biopsy-proven pulmonary sarcoidosis, with a mean age of $37.7 \pm 1.8$ years (all data presented as mean \pm standard error of the mean). There were 16 men and 25 women; 19 were caucasian and 22 were black. Thirty-one $(76 \%)$ were untreated at the time of entry into the study; the remainder were taking prednisone (mean dose $31.3 \pm 2.8 \mathrm{mg}$ per day). For the entire group, the mean duration of symptoms was $37.0 \pm 5.9$ months. Five patients were in radiographic stage 0 (normal chest film); nine were in radiographic stage I (hilar adenopathy only); 11 were in stage II (hilar adenopathy plus pulmonary infiltrate), and 16 were in stage III (infiltrate only). Pulmonary function testing demonstrated mean values as follows: vital capacity $76.9 \pm 2.7 \%$ of predicted; total lung capacity $75.7 \pm 2.7 \%$ of predicted; forced expiratory volume in one second $81.9 \pm 3.3 \%$ of predicted; single breath diffusing capacity $86 \cdot 2 \pm 2.8 \%$ of predicted (based on alveolar volume and haemoglobin); and forced expiratory volume in one second/forced vital capacity of $104 \pm 3.4 \%$ of predicted. ${ }^{17}$

\section{ANGIOTENSIN-CONVERTING ENZYME}

Serum angiotensin-converting enzyme was determined using the radiochemical assay developed by Ryan and co-workers ${ }^{18}$ and marketed by Ventrex Laboratories, Portland, Me. The substrate used was ( $\left.{ }^{3} \mathrm{H}\right)$-hippuryl-glycyl-glycine, and enzyme activity was measured as a function of the amount of $\left({ }^{3} \mathrm{H}\right)$ hippuric acid hydrolysed during a one hour incubation. Enzyme activity was expressed in arbitrary units (units $=$ nanomoles hippuric acid generated/ min-ml serum), with the normal range being 44-125 units (mean $84.5 \pm 2$ SD). The normal range established by Ventrex has been validated by a number of laboratories and was confirmed by our own laboratory using sera from 42 random healthy blood bank donors ( 21 male, 21 female). All patient data were determined using a frozen serum sample obtained by venepuncture within 72 hours of the corresponding lavage and gallium studies. Standard reference sera as well as stored sera were used as controls in the assay.

\section{BRONCHOALVEOLAR LAVAGE}

Bronchoalveolar lavage was carried out as described previously. ${ }^{5} 8$ The percentage of $\mathrm{T}$ lymphocytes in the lavage fluid was determined by rosette formation with neuraminidase-treated sheep red blood cells at $4^{\circ} \mathrm{C}^{6}$

${ }^{67}$ GALLIUM SCANNING

Gallium scans were performed in a standard manner after the intravenous injection of $50 \mu \mathrm{Ci} / \mathrm{kg}$ of gallium-67 citrate. The scans were evaluated using the semiquantitative " $67 \mathrm{Ga}$-index", as previously described, ${ }^{15}$ to minimise the effects of body morphology, imaging technique, and observer subjectivity on scan interpretations.

\section{STAGING OF THE T LYMPHOCYTE}

\section{ALVEOLITIS}

Patients were grouped as having "high intensity alveolitis" or "low intensity alveolitis" using previously described criteria. ${ }^{4}$ High intensity alveolitis includes individuals with lavage $\mathrm{T}$ lymphocytes $>28 \%$ of all recovered cells and a positive ${ }^{67} \mathrm{Ga}$ lung scan $\left({ }^{67} \mathrm{Ga}\right.$-index $>50$ units). Low intensity alveolitis includes individuals with lavage $\mathrm{T}$ lymphocytes $\leqslant 28 \%$ and/or a negative ${ }^{67} \mathrm{Ga}$ scan $\left({ }^{67} \mathrm{Ga}\right.$ index $\leqslant 50$ units). Previous studies have demonstrated that these criteria correlate well with morphological assessment of the alveolitis and with prognosis of the lung disease-that is, stability or deterioration of lung function. ${ }^{416}$ In those individuals who were evaluated more than once, the lavage $\mathrm{T}$ lymphocyte and ${ }^{67} \mathrm{Ga}$-index parameters at the time of each serum ACE value were used. Some individuals who had multiple serum ACE determinations were classified as high intensity alveolitis on some occasions and low intensity alveolitis on others depending on the $\mathrm{T}$ lymphocyte and ${ }^{67} \mathrm{Ga}-$ index values.

\section{DATA ANALYSIS}

Of the total group of 41 patients, 28 had single and 13 had multiple (range 2-5) serum ACE, lavage $\mathrm{T}$ lymphocyte, and ${ }^{67} \mathrm{Ga}$ scan determinations (total 
64 measurements of all three tests in 41 patients). Data on the total number of $T$ lymphocytes recovered via bronchoalveolar lavage and the number of $\mathrm{T}$ lymphocytes $/ \mathrm{ml}$ of lavage fluid were available in 24 patients, of whom 16 had single and eight had multiple (range 2-4) determinations of lavage $\mathrm{T}$ lymphocytes in conjunction with simultaneous serum ACE and ${ }^{67} \mathrm{Ga}$ scans (total 39 measurements in 24 patients). In those instances where more than one measurement of each test was made, each was separated by three to 12 months. Several approaches were used for data analysis.

1 Serum ACE and lavage \% T lymphocytes were compared using the Pearson correlation. This was done using each patient only once $(n=41)$ and using all data from all patients $(n=64)$.

2 Serum ACE levels were compared to lavage \% $\mathrm{T}$ lymphocytes using the Chi-square test. To do this, serum ACE levels were grouped as normal or elevated and the lavage $\% \mathrm{~T}$ lymphocyte data were grouped as $\leqslant 28 \%$ or $>28 \%$. This was done using each patient once $(n=41)$ and using all data from all patients $(n=64)$

3 Serum ACE was compared with total lavage $\mathrm{T}$ lymphocytes recovered and $\mathrm{T}$ lymphocytes $/ \mathrm{ml}$ of lavage fluid using the Pearson correlation. In addition, these parameters were also compared by separating the patients into two groups: those with normal ( $\leqslant 125$ units) serum ACE, and those with elevated ( $>125$ units) serum ACE. For each group, the mean and standard error of total $\mathrm{T}$ lymphocytes recovered and $\mathrm{T}$ lymphocytes/ml of lavage fluid were calculated. The respective means for the two serum ACE groups were then compared using the two-tailed Student's $t$ test (that is, mean total $T$ lymphocytes recovered in the normal serum ACE group versus mean total $\mathrm{T}$ lymphocytes recovered in the elevated serum ACE group; and mean $\mathrm{T}$ lymphocytes/ml of lavage fluid in the normal serum ACE group versus mean T lymphocytes $/ \mathrm{ml}$ of lavage fluid in the elevated serum ACE group). In each instance, these comparisons were done using each patient only once $(n=24)$ and using all data from all patients $(n=39)$.

4 Serum $\mathrm{ACE}$ and ${ }^{67} \mathrm{Ga}$ index values were compared using the Pearson correlation with each patient used once $(n=41)$ and using all data from all patients $(n=64)$.

5 Serum ACE levels were compared to the ${ }^{67} \mathrm{Ga}$ indices using the Chi-square test. To do this, serum ACE levels were grouped as normal or elevated and the ${ }^{67} \mathrm{Ga}$ indices were grouped as $\leqslant 50$ index units or $>50$ index units. This was done using each patient once $(n=41)$ and using all data from all patients $(n=64)$.

6 Serum ACE was compared to the intensity of the alveolitis by grouping the patients as having high intensity alveolitis or low intensity alveolitis and comparing the mean serum ACE levels of the two groups using the two-tailed Student's $t$ test. This was done using each patient once $(n=41)$ and using all data from all patients $(n=64)$.

7 Serum ACE levels were compared to the intensity of alveolitis using the Chi-square test. To do thus, serum ACE levels were grouped as normal or elevated and the patients were grouped as having high intensity alveolitis or low intensity alveolitis. This was done using each patient once $(n=41)$ and using all data from all patients $(n=64)$.

\section{Results}

Comparison of serum ACE levels with bronchoalveolar lavage demonstrated that serum ACE was not able to predict the proportion of lung inflammatory and immune effector cells that were $T$ lymphocytes $(r=0.2), p=0.22$, fig 1$)$. This was true when each patient was analysed once only (fig 1) and when all data from the 41 patients were considered ( $r=0 \cdot 17$, data not shown). In addition, when patients were grouped as having $\leqslant 28 \%$ or $>28 \%$ T lymphocytes in lavage (that level used to define high and low intensity alveolitis, respectively) serum ACE was unable to distinguish between the groups ( $p>0.6$ with each patient evaluated once; $\mathrm{p}>0.12$ with all data from all patients) (table 1 ). Furthermore, no conventional clinical or physiological parameter predicted which patients would have $\%$ T lymphocytes of $\leqslant 28 \%$ or $>28 \%$ (p $>0 \cdot 1$, all comparisons) (table 2).

No significant correlations were found between serum ACE and total $T$ lymphocytes recovered, either with each patient considered once $(r=-0 \cdot 16$, $\mathrm{p}=0.46)$ or using all data from all patients $(\mathrm{r}=-0.13, \mathrm{p}=0.42)$ (table 3). Similarly, no significant correlations were found between serum ACE and $\mathrm{T}$ lymphocytes/ml of lavage fluid when each patient was considered once $(r=-0.12, p=0.58)$ or using all data from all patients $(r=-0 \cdot 14$, $p=0.40$ ) (table 3 ). In addition, when patients were grouped as having normal or elevated serum ACE, they showed no significant differences in mean total $\mathrm{T}$ lymphocytes recovered (each patient considered once, $p>0.6$; all data from all patients, $\mathrm{p}>0.5$ ) or in $\mathrm{T}$ lymphocytes $/ \mathrm{ml}$ of lavage fluid (each patient considered once, $\mathrm{p}>0.4$; all data from all patients, $p>0.4$ ) (table 3 ).

Comparison of serum ACE levels with ${ }^{67} \mathrm{Ga}$ index also demonstrated that serum ACE was not able to predict accurately the uptake of ${ }^{67} \mathrm{Ga}$ by the lung $(r=0.32, p=0.04$, fig 2$)$. While this $p$ value suggests significance, the $r$ value of 0.32 for this 


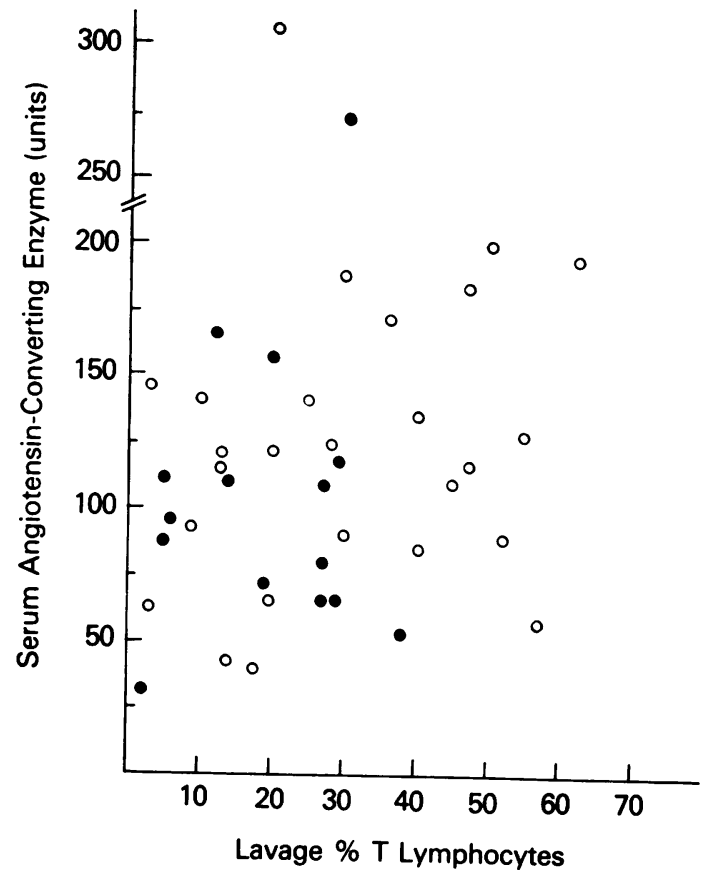

Fig 1 Comparison between serum angiotensin-converting enzyme $(A C E)$ activity and the alveolitis of sarcoidosis as measured by the proportion of lavage cells that are T lymphocytes. High normal value of serum ACE is 125 units. Normal T lymphocytes are $<8 \% ; 28 \%$ is the cut-off level used in the classification of high intensity alveolitis (see text for details). Patients whose ${ }^{67} \mathrm{Ga}$ index was $\leqslant 50$ index units are represented by open circles $(O)$. Patients whose ${ }^{87} \mathrm{Ga}$ index was $>50$ index units are represented by closed circles (O). Each patient in the study is used once in this analysis $(n=41)$. There was no significant relationship between serum ACE and \% T lymphocytes $(r=0 \cdot 2, p>0 \cdot 21)$.
Table 1 Comparison of serum angiotensin-converting enzyme with lavage $T$ lymphocytes, ${ }^{67} \mathrm{Ga}$ scanning, and alveolitis intensity in patients with pulmonary sarcoidosis*

\begin{tabular}{|c|c|c|c|c|}
\hline \multirow[t]{3}{*}{ Parameter } & \multicolumn{4}{|c|}{$\begin{array}{l}\text { Serum angiotensin-converting enzyme } \\
\text { (units) }\end{array}$} \\
\hline & \multicolumn{2}{|c|}{$\begin{array}{l}\text { Each patient } \\
\text { considered once } \\
\text { only }(n=4 I)\end{array}$} & \multicolumn{2}{|c|}{$\begin{array}{l}\text { All data for all } \\
\text { patients considered } \\
(n=64)\end{array}$} \\
\hline & $\leqslant 125$ & $>125$ & $\leqslant 125$ & $>125$ \\
\hline \multicolumn{5}{|l|}{$\%$ T lymphocytes } \\
\hline$\leqslant 28 \%$ & 17 & 6 & 32 & 8 \\
\hline$>28 \%$ & 9 & 9 & 15 & 9 \\
\hline \multicolumn{5}{|l|}{${ }^{\circ} \mathrm{Ga}$ index } \\
\hline$\leqslant 50$ units & 10 & 4 & 15 & 5 \\
\hline$>50$ units & 16 & 11 & 32 & 12 \\
\hline \multicolumn{5}{|l|}{ Alveolitis intensity } \\
\hline High & 20 & 8 & 12 & 7 \\
\hline Low & 6 & 7 & 35 & 10 \\
\hline
\end{tabular}

- Data presented as number of patients in each group; Chi-square analysis used. No significant differences were found in any comparison (p $>0 \cdot 1$, all comparisons).

comparison implies that serum ACE accounts for only $10 \%$ of the variation in gallium index. Even less correlation was found when all data for all patients were analysed $(r=0 \cdot 14, p=0 \cdot 26$, data not shown). In addition, when patients were grouped as having ${ }^{67} \mathrm{Ga}$ indices of $\leqslant 50$ or $>50$ index units (that level used to define high and low intensity alveolitis, respectively), serum ACE was unable to distinguish between the groups ( $p>0 \cdot 22$, all comparisons) (table 2).

Comparison of serum ACE levels with assessment of the alveolitis as measured by the combined criteria of lavage $\% \mathrm{~T}$ lymphocytes and ${ }^{67} \mathrm{Ga}$ index demonstrated that serum ACE was not able to predict the intensity of alveolitis whether each patient was used only once (mean serum ACE \pm SEM for high intensity group $133 \pm 13$; mean serum ACE for low intensity group $110 \pm 12, p=0.23$ ) (fig 3 );

Table 2 Comparison of lavage $\% \mathrm{~T}$ lymphocytes, ${ }^{67} \mathrm{Ga}$ scan, alveolitis intensity, and serum angiotensin-converting enzyme with clinical and physiologic parameters of patients with pulmonary sarcoidosis*

\begin{tabular}{|c|c|c|c|c|c|c|c|c|c|c|}
\hline \multirow[t]{2}{*}{ Parameter } & \multicolumn{5}{|l|}{ Clinical } & \multicolumn{5}{|c|}{ Physiological $\dagger$} \\
\hline & $\begin{array}{l}\text { Age } \\
(y r)\end{array}$ & $\begin{array}{l}\text { Sex } \\
(M / F)\end{array}$ & $\begin{array}{l}\text { Race } \\
(W \mid B)\end{array}$ & $\begin{array}{l}\text { Therapy } \ddagger \\
(Y / N)\end{array}$ & $\begin{array}{l}\text { Duration of } \\
\text { symptoms } \\
(\mathrm{mo})\end{array}$ & $\overline{V C}$ & $T L C$ & $F E V_{1}$ & $F E V_{1} \%$ & $D L C O$ \\
\hline $\begin{array}{l}\text { \% T lymphocytes } \\
\leqslant 28 \% \\
>28 \% \\
{ }^{7} \mathrm{Ga} \text { index }\end{array}$ & $\begin{array}{l}39 \cdot 8 \pm 2 \cdot 4 \\
35 \cdot 0 \pm 2 \cdot 6\end{array}$ & $\begin{array}{l}8 / 15 \\
8 / 10\end{array}$ & $\begin{array}{r}13 / 10 \\
6 / 12\end{array}$ & $\begin{array}{l}7 / 16 \\
3 / 15\end{array}$ & $\begin{array}{l}40 \cdot 0 \pm 7 \cdot 6 \\
33 \cdot 2 \pm 9 \cdot 7\end{array}$ & $\begin{array}{l}77 \cdot 3 \pm 3 \cdot 8 \\
76 \cdot 4 \pm 3 \cdot 9\end{array}$ & $\begin{array}{l}77 \cdot 8 \pm 3 \cdot 2 \\
72 \cdot 9 \pm 4 \cdot 4\end{array}$ & $\begin{array}{l}77.9 \pm 4.6 \\
86.8 \pm 4 \cdot 5\end{array}$ & $\begin{array}{l}96 \cdot 2 \pm 4 \cdot 0 \\
94 \cdot 7 \pm 2 \cdot 9\end{array}$ & $\begin{array}{l}90.4 \pm 3.2 \\
81.0 \pm 4.9\end{array}$ \\
\hline $\begin{array}{l}\leqslant 50 \text { units } \\
>50 \text { units } \\
\text { Alveolitis intensity }\end{array}$ & $\begin{array}{l}39 \cdot 5 \pm 2 \cdot 7 \\
36 \cdot 8 \pm 2 \cdot 4\end{array}$ & $\begin{array}{c}5 / 9 \\
11 / 16\end{array}$ & $\begin{array}{c}7 / 7 \\
12 / 15\end{array}$ & $\begin{array}{l}5 / 9 \\
5 / 22\end{array}$ & $\begin{array}{l}45 \cdot 2 \pm 9 \cdot 9 \\
32 \cdot 7 \pm 7 \cdot 5\end{array}$ & $\begin{array}{l}77 \cdot 1 \pm 4 \cdot 7 \\
76 \cdot 9 \pm 3 \cdot 4\end{array}$ & $\begin{array}{l}75 \cdot 5 \pm 3 \cdot 4 \\
75 \cdot 7 \pm 3 \cdot 7\end{array}$ & $\begin{array}{l}81 \cdot 0 \pm 6 \cdot 7 \\
82 \cdot 3 \pm 3 \cdot 7\end{array}$ & $\begin{array}{l}98 \cdot 9 \pm 3 \cdot 3 \\
95 \cdot 4 \pm 3 \cdot 6\end{array}$ & $\begin{array}{l}84 \cdot 8 \pm 4 \cdot 1 \\
87 \cdot 0 \pm 3 \cdot 9\end{array}$ \\
\hline $\begin{array}{l}\text { High } \\
\text { Low }\end{array}$ & $\begin{array}{l}33 \cdot 1 \pm 2 \cdot 9 \\
40 \cdot 1 \pm 2 \cdot 2\end{array}$ & $\begin{array}{l}7 / 7 \\
9 / 18\end{array}$ & $\begin{array}{r}4 / 10 \\
15 / 12\end{array}$ & $\begin{array}{l}\$ 1 / 13 \\
\$ 9 / 18\end{array}$ & $\begin{array}{l}32.5 \pm 11.6 \\
39.4 \pm 6.9\end{array}$ & $\begin{array}{l}76 \cdot 2 \pm 4 \cdot 9 \\
77 \cdot 3 \pm 3 \cdot 3\end{array}$ & $\begin{array}{l}71 \cdot 3 \pm 5 \cdot 1 \\
77 \cdot 9 \pm 2 \cdot 9\end{array}$ & $\begin{array}{l}86.4 \pm 5 \cdot 3 \\
79 \cdot 4 \pm 4 \cdot 1\end{array}$ & $\begin{array}{l}95 \cdot 3 \pm 2 \cdot 8 \\
99 \cdot 7 \pm 3 \cdot 4\end{array}$ & $\begin{array}{l}81 \cdot 1 \pm 5.6 \\
88.9 \pm 3.2\end{array}$ \\
\hline
\end{tabular}
\$p $<0.05$ between groups. 
Table 3 Comparison of serum angiotensin-converting enzyme with lavage total T lymphocytes and

T lymphocytes/ml in patients with pulmonary sarcoidosis

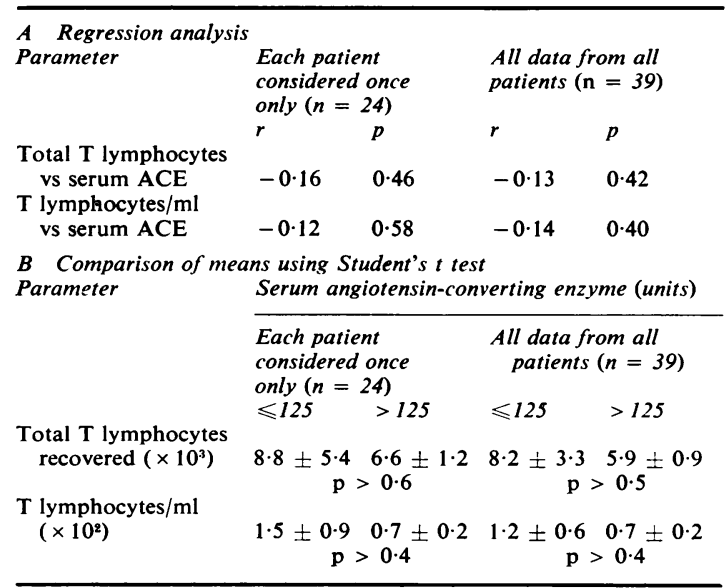

or using all data from all patients (mean serum ACE for high-intensity group $119 \pm 10$; mean serum ACE for low intensity group $105 \pm 8, p=0.32$, data not shown). In addition, when patients were grouped as having high intensity alveolitis or low intensity alveolitis using the combined criteria of lavage $\% \mathrm{~T}$ lymphocytes and ${ }^{67} \mathrm{Ga}$ index, serum ACE was unable to distinguish between groups ( $p>0.23$ with all data from all patients) (table 1). Similarly, no conventional clinical or physiological parameter, with the exception of steroid therapy, predicted which patients would have high or low intensity alveolitis ( $p>0.06$, all comparisons) (table 2). There were significantly fewer patients in the high intensity group who were on therapy at the time of study $(p<0.05)$; this probably resulted from the fact that corticosteroid therapy often converts high intensity alveolitis to low intensity alveolitis. ${ }^{4} 16$

Comparisons were also made between serum ACE levels, lavage $\% \mathrm{~T}$ lymphocytes, and ${ }^{67} \mathrm{Ga}$ index on the one hand, and additional clinical parameters including fever, sedimentation rate, haemoglobin, serum globulins liver function tests, night sweats, and radiographic stage on the other. Neither serum ACE, lavage $\% \mathrm{~T}$ lymphocytes, nor ${ }^{67} \mathrm{Ga}$ index showed any significant correlation with any of the clinical parameters listed above (data not shown).

\section{Discussion}

Angiotensin-converting enzyme is a dipeptidyl hydrolase that converts angiotensin I to angiotensin II and inactivates bradykinin. Since the initial observation that serum angiotensin-converting

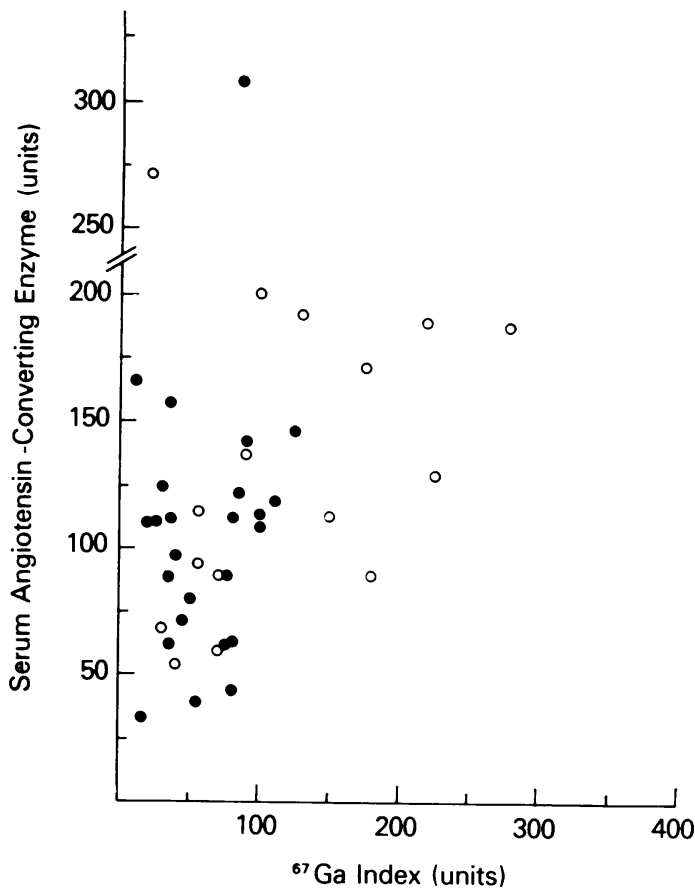

Fig 2 Comparison between serum angiotensinconverting enzyme ( $A C E$ ) activity and the alveolitis of sarcoidosis as measured by the intensity of the ${ }^{67} \mathrm{Ga}$ scan. High normal value of serum ACE is 125 units. Normal ${ }^{67} \mathrm{Ga}$ scans are those with $50{ }^{67} \mathrm{Ga}$ index units; $>50$ index units is a necessary criterion for the classification of high intensity alveolitis (see text for details). Patients whose lavage T lymphocytes were $\leqslant 28 \%$ are represented by open circles ( $\bigcirc)$. Patients whose lavage T lymphocytes were $>28 \%$ are represented by closed circles (O). Each patient in the study is used once in this analysis $(n=41)$. Although the relationship between serum ACE and the intensity of the gallium scan has a $p$ value of 0.04 , an $r$ value of 0.32 suggests this relationship accounts for only $10 \%\left(r^{2}=0 \cdot 1\right)$ of the variability between these parameters.

enzyme was elevated in pulmonary sarcoidosis, ${ }^{19}$ there has been a great deal of interest in the use of serum ACE as a measure of the activity of this disease. ${ }^{20-26}$ However, direct comparison of serum ACE levels with the intensity of the alveolitis of pulmonary sarcoidosis as assessed by lung $T$ lymphocytes and by ${ }^{67} \mathrm{Ga}$ scanning has shown that although serum ACE levels are elevated in many patients with this disease, serum ACE does not reflect accurately disease activity within the lung.

The lack of correlation between lung $T$ lymphocytes and serum ACE in the present study was independent of the way in which the $T$ lymphocyte data were expressed-that is, percentage of total 


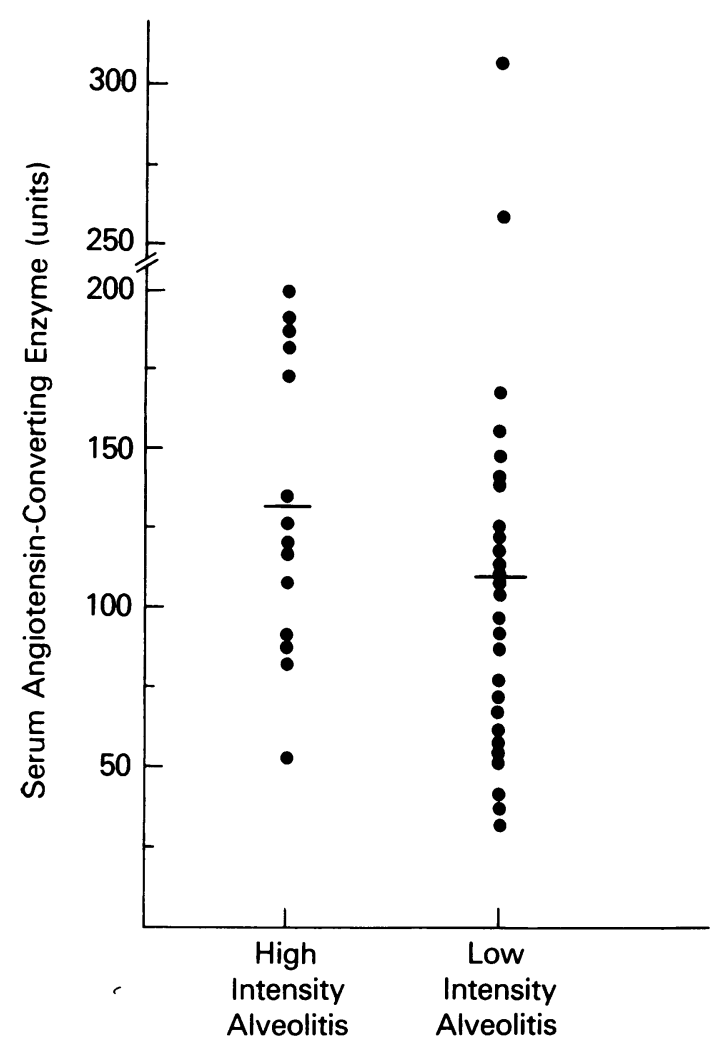

Fig 3 Comparison between serum angiotensinconverting enzyme ( $A C E)$ activity and the intensity of the $T$ lymphocyte alveolitis of patients with pulmonary sarcoidosis as staged by bronchoalveolar lavage and ${ }^{67} \mathrm{Ga}$ scanning. Criteria for high intensity and low intensity alveolitis are listed in the text. Each patient in the study is used once in this analysis. There was no significant difference between the groups $(p>0 \cdot 15)$.

cells recovered by lavage that were $T$ lymphocytes, total number of $T$ lymphocytes in the lavage, or the number of $\mathrm{T}$ lymphocytes $/ \mathrm{ml}$ of lavage fluid. Thus, in no case could a putative relationship between serum ACE and lung $\mathrm{T}$ lymphocytes explain more than $4 \%$ of the data-that is, the largest $r$ value was $0 \cdot 2$. Each of these approaches estimates a somewhat different aspect of the $T$ lymphocyte alveolitis. Percent $T$ lymphocytes expresses the relative emphasis of the lung's immune system toward $T$ lymphocytes, while total $T$ lymphocytes and $\mathrm{T}$ lymphocytes $/ \mathrm{ml}$ of lavage express the total burden (or density per unit volume) of $\mathrm{T}$ lymphocytes within the alveolar structures. Variability studies of lavage analysis have shown remarkable consistency in expressing cell data as a percentage of total lavage cells. ${ }^{5} 8$ In contrast, there have been no studies of the variability (from lobe to lobe or from day to day in a given patient) of expressing the cell data as the total number of each cell type recovered or the number of each cell type/ml of lavage fluid. In addition, although the average volumes of lavage fluid recovered among groups of patients tend to be similar, 5827 there is a wide scatter in the volume recovered for each individual. This variation is likely to be caused by lavage technique, airway geometry, and airway closure during aspiration, all of which are quite independent of either diagnosis or disease activity. Hence, while the number of $\mathrm{T}$ lymphocytes $/ \mathrm{ml}$ gives a somewhat different view of the intensity of the alveolitis in sarcoidosis, there may be too much variability in this approach to gauge accurately the total burden of $T$ lymphocyte within the alveolar structures. These factors may explain the conflicting results in the present study and others ${ }^{28} 29$ in terms of a correlation between serum ACE and the numbers of $T$ lymphocytes recovered per $\mathrm{ml}$ of lavage fluid.

The failure of serum ACE to correlate with the intensity of the alveolitis is sarcoidosis may be the result of a variety of factors. First, the source of the elevated serum ACE is unclear. Studies have implicated alveolar macrophages, ${ }^{30} 31$ circulating monocytes, ${ }^{32}$ and the epithelioid cells of granulomatous lymph nodes ${ }^{33-36}$ as possible sources of the increased levels of serum ACE in some patients with sarcoidosis. In addition, two studies 2631 have demonstrated augmentation of ACE synthesis in tissue culture in response to corticosteroids, the very compounds suspected of lowering serum ACE levels in patients with sarcoidosis. ${ }^{23-25}$

Second, there is a well-documented dichotomy between the peripheral and the pulmonary immune systems in sarcoidosis..$^{6-111314}$ Such divergence is also found in the literature specifically dealing with ACE: (1) ACE activity in lung tissue/mg protein is normal in patients with elevated serum $\mathrm{ACE}^{33}$; (2) Serum ACE does not correlate with levels of ACE produced by alveolar macrophages from patients with pulmonary sarcoidosis maintained in vitro $^{30}$; and (3) Serum ACE does not correlate with levels of ACE in granulomatous lymph nodes from patients with sarcoidosis. ${ }^{36}$

Thus, while elevations of serum ACE are common in sarcoidosis, they are not universal, and do not correlate directly with the alveolitis of the disease. Measurements of serum ACE, although rapid, simple, and non-invasive, do not distinguish patients with high intensity from those with low intensity alveolitis, and thus represent a less precise method of staging these patients. Since the alveolitis of sarcoidosis is not only the precursor of granuloma formation but also represents the reversible com- 
ponent of the disease, it is more accurate to stage the alveolitis by lavage and by ${ }^{67} \mathrm{Ga}$ scanning.

\section{References}

${ }^{1}$ Mitchell DN, Scadding JG. Sarcoidosis. Am Rev Respir Dis 1974;110:774-802.

${ }^{2}$ Mayock RL, Bertrand P, Morrison CE, Scott JH. Manifestations of sarcoidosis: analysis of 145 patients with a review of 9 series selected from the literature. $A m J$ Med 1963;35:67-89.

${ }^{3}$ Sones M, Israel $\mathrm{H}$. Course and prognosis of sarcoidosis. Am J Med 1960;28:84-93.

- Crystal RG, Roberts WC, Hunninghake GW, Gadek JE, Fulmer JD, Line BR. Pulmonary sarcoidosis: a disease characterized and perpetuated by activated lung T-lymphocytes. Ann Intern Med 1981 ;94:73-94.

${ }^{5}$ Weinberger SE, Kelman JA, Elson NA, Young RC Jr, Reynolds HY, Fulmer JD, Crystal RG. Bronchoalveolar lavage in interstitial lung disease. Ann Intern Med 1978; $89: 459-66$.

${ }^{6}$ Hunninghake GW, Fulmer JD, Young RC Jr, Gadek JE, Crystal RG. Localization of the immune response in sarcoidosis. Am Rev Respir Dis 1979;120:49-57.

${ }^{7}$ Hunninghake GW, Fulmer JD, Young RC Jr, Crystal RG. Comparison of lung and blood lymphocyte subpopulations in pulmonary sarcoidosis. In: Williams WJ, Davies $\mathrm{BH}$, eds. Proceedings of the 8th International Conference on Sarcoidosis and Other Granulomatous Diseases. London: Alpha Omega, 1980:426-35.

${ }^{8}$ Hunninghake GW, Gadek JE, Kawanami O, Ferrans VJ, Crystal RG. Inflammatory and immune processes in the human lung in health and disease: evaluation by bronchoalveolar lavage. Am J Pathol 1979;97:149-206.

${ }^{9}$ Hunninghake GW, Kawanami O, Ferrans VJ, Young RC Jr, Roberts WC, Crystal RG. Characterization of the inflammatory and immune effector cells in the lung parenchyma of patients with interstitial lung disease. Am Rev Respir Dis 1981 ;123:407-12.

${ }^{10}$ Crystal RG, Ferrans VJ, Gadek JE, Fulmer JD, Line BR, Hunninghake GW. Interstitial lung disease: current concepts of pathogenesis, staging and therapy. Am J Med $1981 ; 70: 542-68$.

11 Daniele RP, Dauber JH, Rossman MD. Immunologic abnormalities in sarcoidosis. Ann Intern Med 1980;92: 406-16.

12 Biserte G, Chretien J, Voisin C. Le lavage bronchoalveolaire chez l'homme. Paris: Inserm, 1979.

${ }^{13}$ Hunninghake GW, Gadek JE, Young RC Jr, Kawanami O, Ferrans VJ, Crystal RG. Maintenance of granuloma formation in pulmonary sarcoidosis by T-lymphocytes within the lung. $N$ Engl J Med 1980;302:594-8.

${ }^{14}$ Hunninghake GW, Crystal RG. Mechanisms of hypergammaglobulinemia in pulmonary sarcoidosis. $J$ Clin Invest $1981 ; 67: 86-92$.

${ }^{15}$ Line BR, Hunninghake GW, Keogh BA, Jones AE, Johnston GS, Crystal RG. Gallium-67 scanning to stage the alveolitis of sarcoidosis: correlation with clinical studies, pulmonary function studies and bronchoalveolar lavage. Am Rev Respir Dis 1981;123:440-6.

${ }^{16}$ Keogh BA, Hunninghake GW, Line BR, Price D, Young RG Jr, Crystal RG. Alveolitis parameters as predictors of the natural history of pulmonary sarcoidosis. Clin Res $1981 ; 29: 447$ A.

17 Fulmer JD, Roberts WC, Von Gal ER, Crystal RG. Small airways in idiopathic pulmonary fibrosis: comparison of morphologic and physiologic observations. J Clin Invest 1977;60:595-610.

${ }^{18}$ Ryan JW, Chung A, Ammons C, Carlton ML. A simple radioassay for angiotensin-converting enzyme. Biochem $J$ 1977;167:501-4.

${ }^{19}$ Lieberman J. Elevation of serum angiotensin-converting enzyme (ACE) level in sarcoidosis. Am J Med 1975;59: 365-72.

${ }^{20}$ Ashutosh K, Keighley JFH. Diagnostic value of serum angiotensin converting enzyme in lung disease. Thorax 1976;31:552-7.

${ }^{21}$ Studdy P, Bird R, Geraint-James D, Sherlock S. Serum angiotensin-converting enzyme (SACE) in sarcoidosis and other granulomatous disorders. Lancet 1978;2: 1331-4.

22 Turton GWC, Grundy E, Firth G, Mitchell D, Rigden BR, Turner-Warwick $M$. Value of measuring serum angiotensin I converting enzyme and serum lysozyme in the management of sarcoidosis. Thorax 1979;34:57-62.

${ }^{23}$ Gupta RG, Oparil S, Szidon JP. Clinical significance of serum angiotensin converting enzyme levels in sarcoidosis. J Lab Clin Med 1979;93:940-9.

${ }^{21}$ Lieberman J, Nosal A, Schlessner LA, Sastre-Foken A. Serum angiotensin converting enzyme for diagnosis and therapeutic evaluation of sarcoidosis. Am Rev Respir Dis 1979;120:329-35.

${ }^{25}$ DeRemee RA, Rohrbach MS. Serum angiotensin converting enzyme activity in evaluating the clinical course of sarcoidosis. Ann Intern Med 1980;92:361-5.

${ }^{26}$ Baughman RP, Roberts RD, Ploy-Song-Sang Y. Relationship between serum antiotensin converting enzyme and sarcoid activity during steroid therapy. Am Rev Respir Dis 1980;121:110A.

${ }^{27}$ Reynolds HY, Fulmer JD, Kazmierowski JA, Roberts WC, Frank MM, Crystal RG. Analysis of broncho-alveolar lavage fluid from patients with idopathic pulmonary fibrosis and chronic hypersensitivity pneumonitis. $J$ Clin Invest 1977;59:165-75.

${ }^{28}$ Stanislas-Leguern G, Marsac J, Arnoux A, Lecossier D. Serum angiotensin converting enzyme and bronchoalveolar lavage in sarcoidosis. Lancet 1979;1:723.

${ }^{29}$ Rossman MD, Cordillo ME, Dauber JH, Daniele RP. Correlation between serum angiotensin-converting enzyme and bronchoalveolar lymphocytes in sarcoidosis. Chest $1980 ; 78: 537 \mathrm{~S}$.

${ }^{30}$ Hinman LM, Stevens CA, Matthay RA, Reynolds HY, Gee JBL. Lysozyme and angiotensin convertase activity in human alveolar macrophages: the effects of cigarette smoking and pulmonary sarcoidosis. Am Rev Respir Dis 1978;117:67A.

${ }^{31}$ Friedland J, Setton C, Silverstein E. Angiotensin converting enzyme: Induction by steroids in rabbit alveolar macrophages in culture. Science 1977;197:64-5.

${ }^{32}$ Friedland J, Setton C, Silverstein E. Induction of angiotensin converting enzyme in human monocytes in culture. Biochem Biophys Res Commun 1978;83:843-9.

${ }^{33}$ Silverstein E, Friedland J, Lyons HA. Elevation of angiotensin converting enzyme in granulomatous lymph nodes and serum in sarcoidosis: clinical and possible pathogenic significance. Ann NY Acad $S: i$ 1976;278: 498-513.

${ }^{34}$ Silverstein E, Friedland J, Ackerman T. Elevation of granulomatous lymph node and serum lysozyme in sarcoidosis and correlation with angiotensin-converting enzyme. Am J Clin Path 1977;68:219-24.

${ }^{35}$ Silverstein E, Lockerman Z, Friedland J. Serum and lymph node collagenase in sarcoidosis: comparison with angiotensin-converting enzyme. Am J Clin Path $1978 ; 70: 348-51$.

${ }^{36}$ Silverstein E, Friedland J, Lyons HA, Gourin A. Markedly elevated angiotensin converting enzyme in lymph nodes containing non-necrotizing granulomas in sarcoidosis. Proc Natl Acad Sci USA 1976;73:2132-41. 